Grime, J. P. (1972). The creative approach to nature conservation. Pp. 47-54 in The Future of Man: Symposium (Ed. F. J. Ebling \& G. W. Heath). Academic Press, London: $\mathrm{xviii}+211 \mathrm{pp}$.

Helliwell, D. R. (MS.). Survey of Severnside-A Method of Assessing the Conservation Value of Large Areas. Typescript (1969): 4 pp., 1 fig. Copies available from the Author.

Helliwell, D. R. (1973). Priorities and values in nature conservation. J. Environ. Manage., 1, pp. 85-127.

Helliwell, D. R. (1975a). The concept of 'waste' and the conservation of Nature. Environmental Conservation, 2(4), pp. 271--3, fig.

Helliwell, D. R. (1975b). The distribution of woodland plant species in some Shropshire hedgerows. Biol. Conserv., 7, pp. 61-72, 3 figs.

Helliwell, D. R. (in press). The effects of size and isolation on the wildlife conservation value of wooded sites in Britain. J. Biogeog., 3, $10 \mathrm{pp}$. (in press).
Hooper, M. D. (1971). The size and surroundings of nature reserves. Pp. 555-61 in The Scientific Management of Animal and Plant Communities for Conservation (Ed. E. D. Duffey \& A. S. Watt). Blackwell, Oxford: xvi +652 pp.

MacArthur, R. H. (1972). Geographical Ecology: Patterns in the Distribution of Species. Harper \& Row, New York: xviii $+269 \mathrm{pp}$.

Moore, N. W. (1962). The heaths of Dorset and their conservation. J. Ecol., 50, pp. 369-91.

Moore, N. W. \& Hooper, M. D. (1975). On the number of bird species in British woods. Biol. Conserv., 8, pp. 239-50.

Peterken, G. F. (1974). A method for assessing woodland flora for conservation using indicator species. Biol. Conserv., 6 , pp. 239-45.

Pollard, E. (1973). Hedges, VII. Woodland relic hedges in Huntingdon and Peterborough. J. Ecol., 61, pp. 343-52.

Preston, F. W. (1962). The canonical distribution of commonness and rarity. Ecology, 43, pp. 182-215 and 410-32.

\title{
A Major Elephant Conservation Project Launched
}

Heavy poaching of elephants for ivory in recent years has aroused widespread fears that they are threatened with extinction in the near future. Nevertheless, no one knows just how many elephants there are in Africa and Asia, and the situation has been confused by large concentrations of elephants in some areas, whereas they have disappeared from others. To establish a true picture of the situation, and to work out conservation measures, the World Wildlife Fund (WWF) and the International Union for Conservation of Nature and Natural Resources (IUCN) have now launched a three-years project under the overall guidance of Dr Iain Douglas-Hamilton, one of the leading experts on the African Elephant (Loxodonta africana), who is Chairman of IUCN's Elephant Group. The New York Zoological Society is actively associated with the project.

Dr Douglas-Hamilton will concentrate on the African Elephant, working in association with Dr H. Croze, while the Asiatic Elephant (Elephas maximus) study will be supervised by Mr J. C. Daniel, Curator of the Bombay Natural History Society, and Mr Robert Olivier, who has recently been studying this Elephant in Malaysia.

Despite the heavy toll from poaching, experts do not consider the African Elephant to be seriously endangered so far as a species, although they believe that it may disappear from many of its normal haunts.

The Asiatic Elephant, which is of a different genus, is found from India through continental south-east Asia, and on the islands of Sri Lanka and Sumatra. So far only the Sri Lankan subspecies has been included in the IUCN's Red Data Book of Endangered Species, although there is serious concern about the threat to the Asian Elephant in its other strongholds.

Apart from poaching for ivory, the main threat to the elephants is loss of habitat. Many of their.traditional areas have been, or are being, converted to agriculture or settlement, with consequent disruption of the migration routes of wild elephants. As a result, their attempts to continue their normal way of life frequently bring them into conflict with human beings.

While the overall picture is one of rapid decline, a paradoxical situation has developed in many national parks and reserves where elephant numbers have swollen. There the vegetation may be destroyed, resulting in malnutrition of elephants and changes in the local environment which affect a wide range of other animals. Some authorities have suggested that this could even result in elephants becoming virtually extinct in areas that have been set aside for their conservation!

The WWF/IUCN project is scheduled to encompass a survey of the whole ecological spectrum of interactions between Man, elephant, and habitat-including human attitudes towards elephants. It will also include an investigation into the impact of the international ivory trade. As the project develops, areas for action should become apparent, as well as the methods necessary to ensure the conservation of elephants.

Many research projects on elephants have been, or are being, carried out, and the active cooperation of all concerned is being sought. A broad picture of the elephant situation will be established through questionnaires, which should indicate numbers and current ranges. More detailed studies will then be undertaken of the population dynamics of selected populations-particularly the effects of range contraction, expanding human settlement, and poaching.

At the same time, a survey of the ivory trade will permit an assessment to be made of the continuing off-take of elephants and the ecological implications of the trade. This will involve contacts with officials of exporting and consuming nations, and with ivory dealers and shippers. It should, however, be realized that there will always be a considerable flow of ivory on the market, resulting from normal deaths. Meanwhile the information from the survey will help in the development of proposals for legislative action to end illegal ivory trading and in rationalizing elephant exploitation. It is thought that the establishment of a cartel of producing nations, rather like the Diamond Board, might protect the resource while ensuring a stable revenue-thus giving the producer nations a vested interest in good management of their elephants.

Towards the end of the project it is planned to hold an international conference on management of elephants and their habitats, in which people actively involved in elephant research, conservation, and legitimate exploitation, should participate.

PETER F. R. JACKSON, Director of Information World Wildlife Fund

1110 Morges

Switzerland. 